e ISSN-2230-9403 - Visit us : www. researchjournal.co.in Volume 9 | Issue 1 | April, 2018 | 121-133

DOI : $10.15740 / \mathrm{HAS} /$ FSRJ/9.1/121-133

\title{
Effect of temperature and relative humidity on variation of physico-chemical properties of storage and packed jaggery
}

\author{
H.N. Ramya, A. Ashwini and Bharati C. Mirajkar
}

\begin{abstract}
Short term storage of jaggery by different methods under laboratory conditions indicated that the jaggery stored in air tight container for 90 days maintained its quality and colour closely followed by wrapping with alkathene film and packed in paper box covered by polythene pouch as compared to jaggery kept open as it is without covering wrapped with gunny and Hessian cloth or packed with sugarcane trash and stored.
\end{abstract}

Key Words : Jaggery, Storage, Package, Temperature, Relative humidity

How to cite this article : Ramya, H.N., Ashwini, A. and Mirajkar, Bharati C. (2018). Effect of temperature and relative humidity on variation of physico-chemical properties of storage and packed jaggery. Food Sci. Res. J., 9(1): 121-133, DOI : 10.15740/HAS/ FSRJ/9.1/121-133.

H.N. Ramya, Department of Agriculture Engineering, College of Agriculture, Karekere, Hassan (Karnataka) India (Email : ramyahngowda@yahoo.com) 